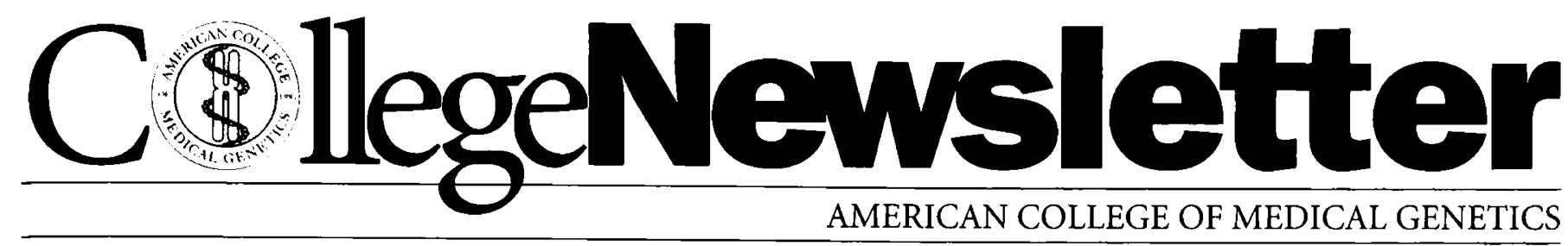

\title{
Forward Motion: Strategic Plan
}

R. Rodney Howell, MD, President

1. We expect to launch the new ACMG Web site by the end of the summer. Members will be notified and given the URL as soon as possible.

2. A subcommittee of the Board met in June to draft a proposal for a streamlined and efficient committee structure for the College that will also maximize member participation. They made recommendations at the July Board meeting, and a final draft will be presented to the membership at the Business Meeting in Philadelphia next October.

3. The Search Committee for the Executive Director of the College and the ACMG Foundation chose five candidates from those who applied and conducted inteniews early in July. An announcement to the membership is anticipated by the end of July.

\section{CommitteeReports}

All ACMG members are invited to attend meetings of the committees and subcommittees. The schedule of meetings for October 2000 (in conjunction with the ASHG meeting in Philadelphia) will be published late summer or early fall.

\section{Clinical Practice Committee (submitted by Lewis B. Holmes, MD, Chair)}

\section{Mission Statement}

The committee shall investigate and report to the Board of Directors on issues which arise from or may impact upon the delivery of clinical genetic services. Such issues may include scientific and medical advances, patient needs, socioeconomic factors, and professional liability concerns. When appropriate, the committee shall study, evaluate, and prepare information for dissemination to members of the College or to the public, subject to approval by the Board of Directors.

\section{Report}

The members of the Clinical Practice Committee and its four subcommittees are listed below. The Committee meets twice a year, in conjunction with the annual meetings of the American College of Medical Genetics and the American Society of Human Genetics.

A major goal of the Clinical Practice Committee is to identify issues of concern to clinical geneticists and to develop helpful responses. These responses have included advocacy, convening groups of interested parties, testifying at government hearings, writing related medical reviews, position statements and letters-to-theeditor, and developing workshops for the annual meeting.

One recent activity has been participating in the Task Force which is preparing the educational document needed to begin to offer cystic fibrosis (CF) screening among pregnant women. The Task Force has included representatives from the American College of Medical Genetics, the American College of Obstetricians and Gynecologists, and the National Human Genome Research Institute. Representatives from NSGC, the CF Foundation, family practice, and pediatrics have also participated. This document, which will be released in late 2000 or early 2001 , provides background information on racial differences in the frequency of CF mutations, highlights potential complex counseling issues, and provides sample brochures to use in counseling and a sample informed consent document.

The subcommittees of the Clinical Practice Committee are: AFP and Related Analytes (Ira S. Salafsky, MD, Chair), Dysmorphology (Christopher M. Cunniff, MD, Chair), Professional Practice and Guidelines (Susan J. Hayflick, MD, Chair), and Adult Diseases (Georgia L. Wiesner, MD, Chair).

The AFP and Related Analytes Subcommittee recently has developed recommendations for first and second trimester screening. The Dysmorphology Subcommittee has developed a prototype informed consent document that includes the option of recognizable photographs being accessible on the Internet. They are also developing for publication a manuscript on the management of the stillborn infant. The Professional Practice and Guidelines Subcommittee is reviewing the practice guidelines developed to date for clinical geneticists and is re-evaluating how best to meet the challenge of developing guidelines for the ACMG. The Adult Diseases Subcommittee polled attendees at the 2000 annual ACMG meeting to identify the top issues for clinical geneticists who provide care to adults. A more extensive questionnaire is being developed for polling a larger number of clinicians. They are also sponsoring an educational session on adult genetic diseases at 
the next annual meetings of the American Society of Human Genetics (2000) and ACMG (2001).

\author{
Members: Clinical Practice Committee \\ Robin L. Bennett, MS, NSGC Liaison \\ Christopher M. Cunniff, MD \\ Alan E. Donnenfeld, MD \\ Susan J. Hayflick, MD \\ Lewis B. Homes, MD (Chair) \\ R. Rodney Howell, MD, ex officio \\ Marilyn C. Jones, MD, ex officio \\ Richard A. King, MD, PhD \\ Roberta A. Pagan, MD \\ Eileen Rawnsley, ISONG Liaison \\ Ira S. Salafsky, MD \\ M. Priscilla Short, MD \\ Georgia L. Wiesner, MD \\ Janet K. Williams, RN, PhD, ISONG Liaison
}

\author{
Members: AFP and Related Analytes Subcommittee \\ Virginia L. Corson, MS \\ Mark I. Evans, MD \\ Inder K. Gadi, PhD \\ Glenn E. Palomaki \\ Ira S. Salafsky, MD (Chair)
}

\author{
Members: Dysmorphology Subcommittee \\ Janice M. Byrne, MD \\ Christopher M. Cunniff, MD (Chair) \\ Cynthia J.R. Curry, MD \\ Christopher Figone, Consumer Representative \\ Louanne Hudgins, MD \\ John B. Moeschler, MD \\ Ann Haskins Olney, MD \\ Richard M. Pauli, MD, PhD \\ Laurie H. Seaver, MD \\ Cathy A. Stevens, MD
}

\section{Members: Professional Practice and Guidelines Sub- committee}

Harold N. Bass, MD

Lisa L. Baumbach, PhD

George C. Cunningham, MD

Susan J. Hayflick, MD (Chair)

W. Alan Hogge, MD

Dale Halsey Lea, RN, MPH, NSGC Liaison

Susan P. Pauker, MD

Beth A. Pletcher, MD

Robert E. Wassman, Jr., MD

Eric A. Wulfsberg, MD

\section{Members: Adult Diseases Subcommittee}

Louise S. Acheson, MD, MS

Wylie Burke, MD

Richard A. King, MD, PhD

Maren T. Scheuner, MD, MPH

M. Priscilla Short, MD

Georgia L. Wiesner, MD (Chair)

\section{Laboratory Practice Committee (submitted by Bradley W. Popovich, PhD, Chair)}

Mission Statement

The committee shall investigate and report to the Board of Directors on issues which arise from or may impact upon the provision of laboratory genetic services. Such issues may include scientific and technological advances, patient and clinical needs, laboratory accreditation, socioeconomic factors, and liability concerns. When appropriate, the committee shall study, evaluate, and prepare information for dissemination to members of the College or to the public, subject to approval by the Board of Directors. The senior member of CAP/ACMG Resource Subcommittees is automatically a member of the Quality Assurance Subcommittee.

\section{Report}

The members of the Lab Practice Committee, the QA Subcommittee and the resource committees are listed below. The Committee meets twice a year in conjunction with the annual meetings of the American College of Medical Genetics and the American Society of Human Genetics. The major goal of the Lab Practice Committee is to monitor and improve the provision of laboratory genetic services. This is accomplished by working closely with the QA Subcommittee (and its Resource Committees) and monitoring the ongoing genetic testing proficiency programs in biochemical, cytogenetic, and molecular genetics. The Lab Practice Committee discusses problems detected by these American College of Medical Genetics and College of American Pathologists (ACMG/CAP) jointly administered proficiency testing programs, and recommends corrective actions. Such recommendations may include revision of the ACMG Standards and Guidelines for Clinical Genetics Laboratories, assembly of a specifically tasked working group, and/or proposing of educational workshop sessions at the annual meeting. Members of the Lab Practice Committee also serve as advocates for issues related to genetic laboratory services including testifying at government hearings, organizing groups of interested parties, writing position statements, improving laboratory reimbursement, and addressing issues related to regulatory oversight.

\section{QA Subcommittee (submitted by Sue Richards, PhD, Chair)}

The mission of the ACMG Quality Assurance (QA) Subcommittee is to develop standards and guidelines for clinical cytogenetic, biochemical, and molecular genetic laboratories with the ultimate goal of improvement in the quality of genetic services. The current ACMG-approved Standards and Guidelines for Clinical Genetic Laboratories that were written by the QA Subcommittee can be found on the ACMG Web site at 
www.faseb.org/genetics/acmg/stds. These standards and guidelines are constantly under revision and expansion by our subcommittee. This subcommittee is challenged with identifying particular areas that need improvement and assessing the importance of developing disease-specific tests or new technologies. Our subcommittee reviews laboratories' performance on CAP/ ACMG proficiency testing and targets areas that need improvement. The molecular component of the subcommittee is completing review of our first disease-specific standards and guidelines document on fragile $X$ testing. Following subcommittee approval, documents circulate to the Laboratory Practice Committee for review, and then to the Board of Directors. Approved documents are then released to ACMG membership and made available at the Web address listed above.

The QA subcommittee, like all ACMG committees, is composed of volunteers from the ACMG membership. All subcommittee members are ABMG-certified clinical genetic laboratory directors of either cytogenetic, biochemical, or molecular laboratories.

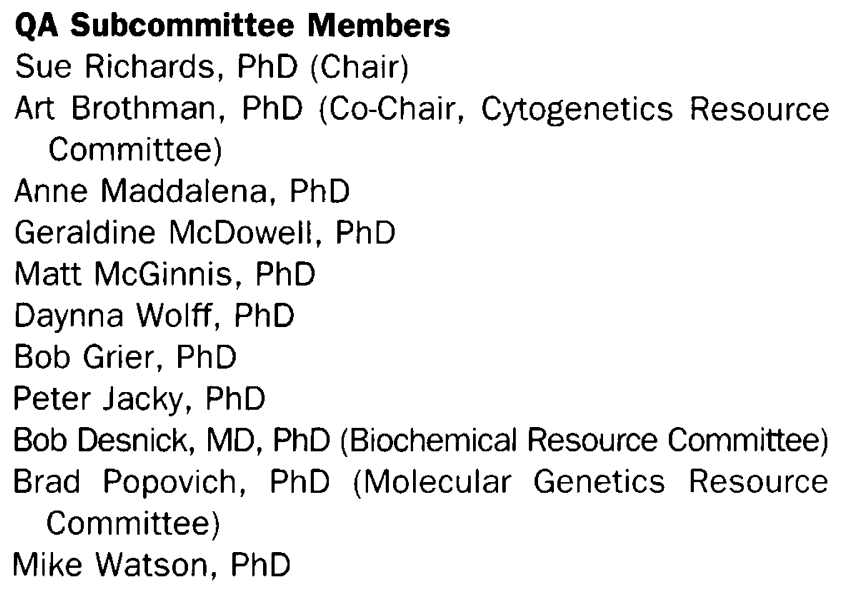

\section{Working Group on the Interpretation and Reporting of Sequence Variation}

The Lab Practice Committee assembled a Working Group to investigate and make recommendations for the standardization of interpretation and reporting of sequence variations identified in the course of providing clinical laboratory services. This group, chaired by Haig Kazazian, Jr., MD, will publish its recommendations in Genetics in Medicine in the near future. These recommendations will provide a standardized framework for the interpretation and reporting of such test results, and will aid referring clinicians by educating them as to possible testing outcomes so that they may inform their patients and families appropriately. Other members of this working group include Corinne Boehm, MS, and William Seltzer, PhD.

\section{Working Group on the Detection of Organic Acids}

A Working Group was assembled by Lab Practice to investigate and make recommendations related to the detection of organic acids. This group (Steve Goodman, $M D$, chair; Bill Nyhan, MD, PhD, cochair; Mike Gibson, $\mathrm{PhD}$, and Piero Rinaldo, MD) has submitted proposed revisions to the Standards and Guidelines, and will be sponsoring a workshop at the ACMG Annual Meeting in Miami in 2001.

Members of the Lab Practice Committee are currently participating in, advising, or providing testimony to several national groups involved in discussions on, or related to, genetic testing. These include:

1) The Secretary's Advisory Committee on Genetic Testing: http://www4.od.nih.gov/oba/sacgt.htm

2) The Centers for Disease Control Genetics Forum: The CDC has sponsored two Genetic Forum meetings to date with the focus on the proposed revisions of CLIA (see Notice of Intent, published May 4, 2000, Federal Register). The CLIAC has proposed that the rules be augmented in CLIA with specific assurances of quality in labs performing genetic testing. The Lab Practice Committee, represented by Bradley Popovich, PhD, R. Rodney Howell, MD, and Michael Watson, PhD, has been an active participant in these discussions.

3) The US Patent and Trademark Office

4) The Health and Human Services Interagency Working Group on Genetic Testing

\author{
Members: Laboratory Practice Committee \\ Bradley W. Popovich, PhD (Chair) \\ Wayne W. Grody, MD, PhD (CAP Liaison) \\ Thomas W. Prior, PhD \\ Michael S. Watson, PhD \\ David Ledbetter, PhD \\ Michelle LeBeau, PhD \\ Lynn Fleisher, PhD, JD \\ R. Rodney Howell, MD (ex officio) \\ Edward R.B. McCabe (ex officio)
}

\section{Biochemical and Molecular Genetics Resource Committee}

The mission of the Biochemical and Molecular Genetics Resource Committee is to develop, maintain and enhance proficiency testing programs to reflect the state of the art in both biochemical and molecular genetics; to function as a resource to a variety of CAP and ACMG committees and commissions; to develop an interface with various agencies and organizations concerned with defining and maintaining excellence in both biochemical and molecular genetics; and to contribute to the continuing education of members of the CAP and ACMG through surveys, critiques, publications, and participation in CAP and ACMG education programs.

\section{Members}

Wayne Grody, MD, PhD (Chair, CAP, Molecular Genetics) 
Bob Desnick, MD, PhD (Co-Chair, ACMG, Biochemical Genetics)

Walter Noll, MD (CAP, Molecular Genetics)

Steve Goodman, MD (ACMG, Biochemical Genetics)

John Eckfeldt, MD, PhD (CAP, Biochemical Genetics)

Brad Popovich, PhD (ACMG, Molecular Genetics)

Tim Stenzel, MD, PhD (CAP, Molecular Genetics)

Bill Nyhan, MD, PhD (ACMG, Biochemical Genetics)

Ron McGlennen, MD (CAP, Molecular Genetics)

Tom Prior, PhD (ACMG, Molecular Genetics)

Jeff Kant, MD, PhD (CAP, Molecular Genetics)

Karen Snow, PhD (ACMG, Molecular Genetics)

Elizabeth Rohlfs, PhD (Liaison, AACC, Molecular Genetics)

\section{Cytogenetic Resource Committee}

The mission of the Cytogenetics Resource Committee is to develop, maintain, and enhance proficiency testing programs to reflect the state of the art in cytogenetics; to function as a resource to a variety of CAP and ACMG committees and commissions; to develop an interface with various agencies and organizations concerned with defining and maintaining excellence in cytogenetics; and to contribute to the continuing education of members of the CAP and ACMG thought surveys, critiques, publications, and participation in CAP and $A C M G$ education programs.

\author{
Members \\ Linda Cooley, MD (Chair, CAP) \\ Art Brothman, PhD (Co-Chair, ACMG) \\ Nancy Schneider, MD, PhD (CAP) \\ Kathleen Rao, PhD (ACMG) \\ Gail Habegger Vance, MD (CAP) \\ James Mascarello, PhD (ACMG) \\ Jonathan Park, PhD (Liaison, AACC)
}

\section{Economics of Genetic Services Committee (submitted by Michael $\mathbf{S}$. Watson, PhD, Chair)}

Mission Statement

The committee shall study and assess billing and reimbursement mechanisms for medical genetic services with the goals of (1) ensuring appropriate integration of genetic services into evolving national, state, and private health care schemes; (2) educating medical geneticists regarding appropriate procedures to be followed; and (3) maintaining and improving patient access to medical genetic services.

\section{Report}

The Economics of Genetic Services Committee has been busy with both new and old projects as well as maintaining our participation in committees of the AMA involved with these issues. David Flannery continues as our appointed representative to the CPT Advisory
Committee and Wayne Miller has begun as our representative to the RUC (RBRVS Update Committee). Among old projects are our continuing efforts to obtain new CPT codes for pedigree development and analysis and genetic risk assessment. The CPT Editorial Panel rejected the first proposal because they had recently decided to develop an area on counseling (generically), which would alter the distribution and descriptions of work in our proposal. We are working with AMA as the counseling area is addressed. This is the result of an effort by AMA to enhance the coding options for nonphysician work. A recent project now nearing completion and directed by Robert Greenstein is developing a manual on billing and reimbursement for genetic services. In addition to some general information, the manual will focus on unique or difficult aspects of genetic services billing in Medicare, Medicaid, managed care and other payer systems, and provides standardized forms and commonly used information. In the laboratory area, a subcommittee is forming which will work with several other groups with interests in genetic tests including the College of American Pathologists. The group is finalizing the analysis of cost information from labs across the country, which will serve as an educational document for HCFA and other payers in order that they might make appropriate decisions about reimbursement levels for genetic testing. This group will also be assessing the next generation of genetic tests involving various multiplexing strategies such as $\mathrm{mi}$ croarrays, gene chips, and others as to how such tests should be coded in CPT.

\author{
Members: Economics of Genetic Services \\ Carolyn A. Bay, MD \\ Debra Lochner Doyle, MS \\ David B. Flannery, MD \\ Robert M. Greenstein, MD \\ Lewis B. Holmes, MD \\ Ronald J. Jorgenson, DDS, PhD \\ Wayne Miller, MD \\ Bradley W. Popovich, MS, PhD \\ Cheryl S. Reid, MD \\ Wendy S. Rubinstein, MD, PhD \\ Maren T. Scheuner, MD, MPH \\ Eva Sujansky, MD \\ Michael S. Watson, PhD (Chair) \\ Luann Weik, MS, NSGC Liaison \\ Marc S. Williams, MD
}

\section{Patents Subcommittee (submitted by Michael S. Watson, Chair)}

Report

As briefly discussed in the report of the GLAC committee, the Patents Subcommittee has been quite active. We participated in a meeting earlier this year in Washington, which included NHGRI, and PTO, which was cosponsored by ACMG, titled "A Public Dialogue 
on Gene Patenting." This same topic is scheduled for discussion at the June meeting of the Secretary's Advisory Committee on Genetic Testing (SACGT) and will be among the Workshops at this year's ASHG meeting. The ACMG position statement opposes gene patenting and expresses concern about the licensing agreements for use of the patented information. The short term focus is on licensing issues since the question of gene patenting is a much broader societal question which needs to be addressed by a broadly representative group of individuals. The goal in licensing is to ensure the public has affordable access to testing without compromising training programs for the next generation of laboratorians. Of critical importance is that aspects of genetic testing which are considered to be within the practice of medicine (e.g., interpretation of sequence variation) not be constrained. In this regard, changes in the Ganske legislation, which holds a physician harmless for infringing a patent on a medical procedure, be extended to include present day highly manual testing methods. The ACMG position statement on gene patenting can be found at the ACMG Web site. Lastly, the ACMG has put forth resolutions to the House of Delegates of the AMA to seek the participation of the AMA's infrastructure in dealing with this rapidly developing problem. These were presented by Raymond Lewandowski at their June meeting and are already supported by a number of other groups.

\author{
Members: Patents Subcommittee \\ Lynn D. Fleisher, PhD, JD \\ Bradley W. Popovich, PhD \\ Reed E. Pyeritz, MD \\ Carolyn Sue Richards, PhD \\ Michael S. Watson, PhD (Chair)
}

\section{Membership Committee (submitted by John A. Phillips III, MD, Chair)}

Mission Statement

The committee shall (1) review applications for membership in the College and recommend qualified applicants to the Board of Directors for election to membership; (2) annually review the membership of the College to determine whether action is needed to maintain a proportional Fellowship and recommend such action, when necessary, to the Board of Directors; (3) periodically reassess membership classes and qualifications and report their findings to the Board of Directors; (4) develop programs for the promotions and retention of membership in the College; and (5) consider applicants' petitions for exceptions to membership qualifications and recommend appropriate exceptions, if any, to the Board of Directors.

\section{Report}

The Membership Committee is happy to report a significant increase in members. Total membership was
$1055,1078,1110$, and 1158 as of October and December of 1999 and February and March of 2000. This growth represents a $10 \%$ increment in new members. Of our 1110 members as of February 2000, 859 or $77 \%$ were Fellows. Of the Fellows, $62 \%$ are MDs and $38 \%$ are PhDs. Of the 534 MD Fellows, 55\% are AMA members. We encourage MD Fellows who are not AMA members to join the AMA. This will ensure our continued membership in the AMA House of Delegates and our participation in policy decisions at the national level. Those joining the AMA should notify the ACMG office so that we can be sure to maintain the required $51 \%$ of MD Fellows as AMA members.

\author{
Members: Membership Committee \\ Judith Benkendorf, MS \\ Sechin Cho, MD \\ Lewis B. Holmes, MD \\ Marilyn C. Jones, MD \\ Robert R. Lebel, MD \\ John A. Phillips III, MD (Chair) \\ Bradley W. Popovich, PhD
}

\section{Social, Ethical, and Legal Issues Committee (submitted by Mary Kay Pelias, JD, PhD, Chair)}

Mission Statement

The committee shall consider and report to the Board of Directors on social and ethical issues which arise from or may impact upon the delivery of clinical genetic or laboratory genetic services. Such issues may include access to medical genetic services, informed consent, confidentiality, disclosure of genetic information to third parties, and discrimination based on genetic status. When appropriate, the committee shall study, evaluate, and prepare information for dissemination to members of the College or to the public, subject to approval by the Board of Directors.

\section{Report}

The Social, Ethical, and Legal Issues Committee addressed several issues during its meeting in Palm Springs on March 9, 2000. Members are participating in three on-going projects, two of which are expected to be completed during this year.

The Boards of Directors of ACMG and ASHG approved a points-to-consider paper on "Genetic Testing in Adoption." Mark Rothstein, representing ASHG, with Mary Kay Pelias, representing ACMG, as second author wrote the paper. This article revisits policy issues first addressed by ASHG in 1991. The article can be found in the American Journal of Human Genetics, 66 (no.3): 755-760, 2000, and on the ACMG Web site.

Matt McGinniss, with Barry Thompson, heads a new study of "DNA Banking for Forensics" for ACMG, and Mark Rothstein for ASHG, with collaboration by representatives of ISONG and NSGC. This paper will address 
the issues of obtaining and storing blood samples from all persons who are arrested and entered into the criminal justice system. Several persons have noted that the narrow focus of forensics may point to an examination of the broader, nonforensic issues of stored tissue samples in pathology collections and in newborn screening programs. The authors will determine the scope of the report as the study advances.

The committee will also examine briefly the "Criteria for Expert Testimony." This short paper will be assembled by Matt McGinniss and circulated to committee members, with a view to presenting the document to the Board of Directors in the fall of 2000 . The interests of genetics professionals will be examined in the light of guidelines of the American Academy of Pediatrics, the American Bar Association, and the American Trial Lawyers Association.

A third new project, on "The Professional-Patient Relationship in Medical Genetics and Genetics Research," will be another joint effort of the committees of ACMG and ASHG. Mary Kay Pelias will take the lead on this paper, with second authorships by Bonnie LeRoy and Jeff Botkin of ASHG. This paper will address questions of disclosure of information, informed consent, re-contacting patients and subjects, and the institutional review process. It will be circulated to other genetics organizations with invitations for endorsement.

Publication of this study is anticipated in Genetics in Medicine.

The committee briefly discussed current controversies in gene therapy and decided not to launch a project in this area at this time. However, the committee is open to suggestions about whether the College should address these questions, and if so, how.

\author{
Members: Social, Ethical and Legal Issues Commit- \\ tee \\ Rebecca R. Anderson, JD, MS \\ Lynn D. Fleisher, JD, PhD \\ Thomas D. Gelehrter, MD \\ Lynn Godmilow, MSW \\ Matthew J. McGinniss, PhD \\ Mary Z. Pelias, PhD, JD (Chair) \\ Barry $\mathrm{H}$. Thompson, MD
}

\section{Education and Continuing Medical Education Committee (submitted by Bruce R. Korf, MD, PhD, Chair)}

Mission Statement

The committee shall (1) study and evaluate various aspects of medical genetic education; (2) review and recommend proposed changes in medical genetic education; (3) consider and recommend means by which the College may provide information, direction, and leadership in the field of medical genetic education; (4) consider and recommend policies and procedures by which clinical and laboratory geneticists may be as- sisted in maintaining their professional competence, including continuing medical genetic education, and develop criteria whereby such achievement may be recognized; and (5) plan, organize, and conduct various educational activities of the College.

\section{Report}

The Education Committee has focused on a number of ongoing initiatives, and has, in addition, launched some important new activities.

A major mission of the committee has been to organize the ACMG CME program. Dr. Jessica Davis has spearheaded this effort, having prepared the proposal to the ACCME that resulted in provisional approval of the ACMG to organize and run CME activities. The 2000 meeting in Palm Springs was site visited by a representative of the ACCME. The next step is to present a self-study report, which will occur this summer. We are hopeful that full accreditation of the college CME program will be in place by the end of the year. Dr. Mary Curtis has joined Drs. Davis and Korf in preparing this self-study report.

The strategic planning process undertaken by the ACMG during the past year has highlighted several areas of importance for the membership regarding educational activities. Two key areas that have emerged are communication within the membership and professional recognition. A major opportunity to improve communications is the upgrading of the college Web site. Earlier this year, bids were reviewed from design firms and one was chosen, CM Design, to take on the project. It is planned for the new Web site to include information for College members, the general public, and the medical community. Committee activities, including committee reports, will be posted on the site. In addition, policies and guidelines of the College will be included. There will be information about CPT coding, as well as an up-to-date directory of the membership. Shared files will be created, making it possible for committee members to edit documents online, which should streamline the process of crafting joint statements. The Web site should be up and running by the end of the summer.

In the area of professional recognition, several new initiatives have been launched. Dr. Curtis has commissioned a set of articles for the journal Postgraduate Medicine on medical genetics. These articles highlight the role of genetics in medical practice, and showcase members of the ACMG, who have served as authors. Dr. Curtis wrote an editorial in the first issue in this series and Dr. Korf will write another editorial in an upcoming issue. Dr. Raye Lynn Alford is chairing an effort to develop slide sets that will be available to the membership to use in teaching colleagues about the value of genetic services. The first one planned will address the evaluation of hereditary hearing loss, and should be available for review this fall. Finally, the Education 
Committee continues to work along with Dr. Priscilla Short of the American Medical Association. Dr. Short has been exploring the potential of setting up training programs jointly with other professional organizations to educate their members about the role of genetics in medical practice.

\author{
Members: Education and Continuing Medical Educa- \\ tion Committee \\ Raye Lynn Alford, PhD \\ Mary A. Curtis, MD (CME Co-Chair) \\ Jessica G. Davis, MD (CME Co-Chair) \\ Helga V. Toriello, PhD \\ Paula E. Gregory, ASHG Liaison \\ Susan J. Hayflick, MD \\ Lewis B. Holmes, MD \\ Richard A. King, MD, PhD \\ Bruce R. Korf, MD, PhD (Chair) \\ Rizwan Naeem, MD \\ Roberta A. Pagon, MD \\ John A. Phillips, III, MD \\ Robert T. Pilarsky, MS (NSGC Liaison) \\ Bradley W. Popovich, PhD \\ Cynthia M. Powell, MD \\ Richard M. Roberts, MD, PhD \\ M. Priscilla Short, MD
}

\section{Governmental and Legislative Affairs Committee (submitted by Carol L. Greene, MD, and Maimon M. Cohen, PhD, Chair)}

\section{Mission Statement}

The committee shall oversee the monitoring of federal and state legislation that may impact on the practice of clinical or laboratory genetics or on the provision of or access to medical genetic services. The committee shall study, evaluate, and recommend to the Board of Directors or to the Public Policy Committee actions that the College may take in the interest of furthering the objectives of the College, the needs of College members, or the public health.

\section{Report}

Patents-There are no current legislative proposals, but a great deal of productive activity is ongoing, and some progress is being made. There has been a lot of public notice taken in local and national news.

There is a critical distinction between the issue of patenting genes and of licensing and royalty rights. Efforts to protect access to genetic technology for clinical and research purposes must focus on licensing and royalty issues to be effective.

Michael S. Watson has been extremely active and effective on behalf of the College, and individuals who are interested in details should contact him.

Several weeks ago, the patent office announced intent to use more narrow criteria (with respect to clinical utility) in determination of eligibility for a patent. The proposed guidelines are open for comment until March 22 , and can be found on the Web (http://for webgate.access.gpagov/cgi-bin/getdoc.cgi?dbname = 1999register\&docid $=99-33,054$-filed). There remains concern that these new guidelines are still not sufficient to protect public access to genetic technology.

Genetic Discrimination-Several proposals are before Congress and the Executive Branch, and several states have demonstrated activity related to genetic discrimination.

An Executive Order was announced on February 8 that prohibits empioyment discrimination in federal workplaces. While the number of individuals affected by the Order is small compared to the entire national workforce, the gesture is an important milestone and indicates significant support from the President.

Senate 1322 (Daschle, Harkin, Dodd, Kennedy) and House 2457 (Slaughter) are currently before Congress. The genetics community has had significant input into these bills, which focus on the need to prevent use of predictive genetic information as a basis for discrimination in health insurance and in employment.

Kennedy staffer David Bowen has requested information about individuals who have experienced discrimination in health insurance or employment as a result of predictive genetic information. Anyone with such information should mail it to Kennedy Health Staff/David Bowen at 527 Hart Senate Office Building Washington DC 20,510 .

Licensing Genetic Counselors-The College has a strong interest in promoting the licensure of genetic counselors, and wants to work with NSGC on this issue. New Jersey and California currently have efforts in progress.

The Committee discussed the need for developing model legislation for sharing examples of success, and to develop improved communication between sectors of the genetics community and other health care providers. It was proposed to develop a task force including members of the ACMG, NSGC, AAP, and ACOG.

Genetics and Public Health Services Act (S 1981, Kennedy) - So far, there has been no legislative action this year. APHA has not been active on this issue this congressional session. There is some behind-thescenes activity recently at HHS that indicates that $\mathrm{HHS}$ may be interested to push the proposal. Therefore, there may still be some action this year, but most likely next year. If there is going to be action this year, we must be prepared to move quickly.

The proposal has significant support, and opponents are most likely to focus on cost, state match, and risk of use of genetic information in a way not acceptable to some sectors of the general public and lawmakers. It is important that individuals who would like to work 
in support of the bill be fully educated about all issues before engaging in any advocacy efforts.

Infrastructure and Resources for ACMG Activities in Policy and Legislation-The College does not have a lobbyist. The Board plans to hire an Executive Director. The Committee recommends that the College proceed as quickly as possible to add D.C. government and legislative affairs staff.

Until that time, Carol Greene proposed that the GLAC Committee make an effort to accomplish specific tasks necessary for the College to promote the Public Health Genetics Services Act. Before College members can engage in effective educational activities, the College will need to prepare materials such as talking points, fact sheet, background information, and teaching materials on lobbying. Volunteers should contact Carol Greene-she is listed in the ASHG membership directory (greene.carol@tchden.org).

The Committee briefly discussed again the need for rapid and interactive communication between the ACMG Board, GLAC and College membership. The improvements planned for the Web site should be most useful. Finally, the Committee discussed the need for organized interaction between ACMG and sister organizations with respect to policy and legislative issues.
Members: Government and Legislative Affairs Committee

Harvey A. Bender, PhD

Joel Charrow, MD (Long-term CMSS representative)

Maimon M. Cohen, PhD (Chair)

Louis J. Elsas, MD

Nancy L. Fisher, MD

Betsy Gettig, MS

Carol L. Greene, MD

Craig Higgins, NHGRI Liaison

Lewis B. Holmes, MD

R. Rodney Howell, MD

Marilyn C. Jones, MD

Edward R. B. McCabe, MD

Bradley W. Popovich, MS, PhD

Reed E. Pyeritz, MD, PhD

Devereux N. Saller, Jr,. MD

Joe Leigh Simpson, MD

\section{Joint Test and Technology Committee of the ACMG/ASHG}

The joint ASHG/ACMG Test and Technology Transfer Committee has a number of policy statements in progress, including FISH, Colon Cancer, and Uniparental Disomy. Look for more details in the September/ October issue of Genetics in Medicine. 